\title{
Pelizaeus-Merzbacher disease, classic form
}

INSERM

\section{Source}

INSERM. (1999). Orphanet: an online rare disease and orphan drug data base. PelizaeusMerzbacher disease, classic form. ORPHA:280219

The classic form of Pelizaeus-Merzbacher disease (PMD) is the infantile form of PMD. 